\title{
History Matters? \\ History's Role in Health Policy Making
}

\author{
VIRGINIA BERRIDGE*
}

"History matters - pass it on" was the slogan of a campaign launched in England in the summer of 2006 to raise public awareness of the huge contribution that history, heritage and the built environment make to our quality of life. A resumé commented,

It unites the whole heritage sector, led by the National Trust, English Heritage, the Historic Houses Association and the Heritage Lottery Fund, and events will be held over the next six months at hundreds of historic locations across England and Wales. Supporters include David Starkey, Tristram Hunt, Simon Thurley, Stephen Fry, Bill Bryson, Shami Chakrabarti, Tony Benn and Boris Johnson. ${ }^{1}$

The comedian and writer Stephen Fry in an accompanying article, drew attention to the enormous public appetite for history, from family history through to television reconstruction. Fry found it difficult to articulate just why history did matter. "We know that history matters, we know that it is thrilling, absorbing, fascinating, delightful and infuriating, that is life. Yet I can't help wondering if it's a bit like being a Wagnerite; you just have to get used to the fact that some people are never going to listen." Yet Fry saw history as imparting moral and ethical principles and a sense of relativism and self-criticism. "We criticize the slave trade now: what will future generations criticize us for? Eating meat, driving cars? We could see the value of scientific discovery; could we test the value of history in the same way? Can we prove that a politician, a financier or spotwelder is better, happier or more fulfilled for possessing a feel for history?"

This discussion paper has its origin in part of Fry's agenda. It looks at a little discussed sector of historical enthusiasm: the use made of history by politicians involved in health policy making and by those who advise them. In a previous study, I examined cross national variation in how history was used in public discussion and drew on the views of historians who had been involved in the relationship with policy in different areas. ${ }^{2} \mathrm{My}$ conclusions then were that this was a relationship which was itself historically contingent, variable according to factors like timing and national location. The current work researched the relationship from a different angle, examining how history was viewed from the policy level, by policy makers. The question was not Fry's one of whether politicians were better and happier for possessing a feel for history, but rather whether the insights of history and

(C) Virginia Berridge 2008

*Professor Virginia Berridge, Centre for History in Public Health, London School of Hygiene and Tropical Medicine, Keppel Street, London WC1E 7HT, UK.

I am most grateful to the history and policy network for its funding of this project and to my colleagues at the LSHTM for their input and advice.

\footnotetext{
${ }^{1}$ Stephen Fry, 'The future's in the past', Observer, 9 July 2006.

${ }^{2}$ Virginia Berridge, 'Public or policy understanding of history?', Soc. Hist. Med., 2003, 16 (3): 511-23.
} 


\section{Virginia Berridge}

historians had actually been drawn upon in the making of policy and, if they had, in what ways. What could this tell us about the impact of history, how that happened and how the relationship with policy might be developed?

\section{How the Study was Carried Out}

The study involved a set of interviews with fifteen "key informants" who had been involved in the policy process in different ways. ${ }^{3}$ It was specifically organized to examine health policy making and does not make claims for any uses of history beyond those boundaries. As my previous paper noted, different government departments have different traditions of using history and of generating it. ${ }^{4}$ The location of the Centre for History in Public Health in a policy-related public health institution was an important source of contacts: other interviews followed through "snowballing" and the networks available through the health location. Different forms of policy advice were explored. Some informants had been or were chairing expert committees advising government; others had spent time within government advising ministers. One was an official speechwriter. A list is provided below giving types of informant but not names since most interviews were conducted under terms of anonymity. ${ }^{5}$ No interviews were carried with civil servants, although I did interview academics who had worked within the civil service as policy advisers. I also drew on my own contacts with civil servants and their response to history during the recent Foresight exercise on psychoactive substances. There was no attempt to cover all areas of health policy. Because policy advisers had mostly dealt with the NHS, that was the main focus of comment; the expert committees dealt with two other high profile areas of government health policy. The project provided an opportunity to see how historians and history were perceived by broadly sympathetic people with governmental experience. ${ }^{6}$ There was no set questionnaire; informants were questioned informally about whether history was used at all in the areas in which they had operated; if so, in what ways, and with what impact. Some attention was paid to whether historical interpretations were used and, if so, which historians had been influential. No politicians were interviewed directly, but their speeches and other publications were studied. The study only dealt with the UK.

In addition to the core study, this discussion also draws on the author's recent experience in a number of policy-related exercises, in particular the Office of Science and Technology initiative on the future of psychoactive substances; and some initiatives on the future of alcohol policy. ${ }^{7}$ However, in general I steered clear of drug and alcohol policy in favour of

\footnotetext{
${ }^{3}$ The interview part of the study was funded by a small grant from the funding given by an anonymous donor to the History and Policy network of which the Centre for History in Public Health is a member. The interview part of the study was approved by the LSHTM ethics committee.

${ }^{4}$ Berridge, op. cit., note 2 above. The use of historians "in house" is one difference between health and the Foreign Office, for example.

${ }^{5}$ The interviewees were the following: 1 health services researcher with policy experience; 1 director
}

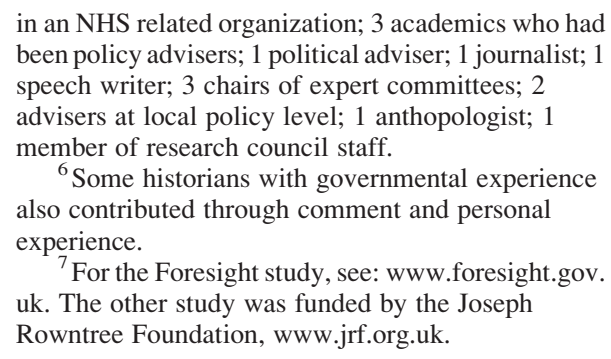

in an NHS related organization; 3 academics who had been policy advisers; 1 political adviser; 1 journalist; 1 speech writer; 3 chairs of expert committees; 2 advisers at local policy level; 1 anthopologist; 1 member of research council staff.

${ }^{6}$ Some historians with governmental experience also contributed through comment and personal experience.

${ }^{7}$ For the Foresight study, see: www.foresight.gov. uk. The other study was funded by the Joseph Rowntree Foundation, www.jrf.org.uk. 


\section{History's Role in Health Policy Making}

areas in which I had not been involved. In the course of the study I was contacted to contribute to a politician's speech and I have drawn on that experience here.

\section{Findings: Politicians Speak}

History was quite often used at the political level in the early twenty-first century in political debate and argument on health policy. Often this involved an invocation of the early history of the NHS and Nye Bevan. In a debate on health and pensions in November 2002, Alan Milburn spoke of how:

... it is an enormous strength to have an NHS providing services that are free, and based on need, not on ability to pay. The NHS provides what some call the security-what Nye Bevan called the "serenity" - of knowing that we all pay in when we are able to do so, so that we can all take out when we need to. ${ }^{8}$

History was used in a different way in the strong political advocacy of local differentiation in health. This was justified by the history of mutualism. The argument of the then Health Secretary, John Reid, for foundation hospitals in the early 2000s was based on his view that they rejuvenated that mutual tradition-alongside the heritage of Nye Bevan. The heritage of the post-1948 state was seen as in need of modernization, but a rethink based on the past.

The 1945 Labour Government, in going for a policy which equated uniformity with equality, neglected the Labour movement's tradition of co-operation and mutualism. The success of the politics of nationalisation and central government organisation under that government had a severe impact on the development of that tradition....

Nye Bevan himself spent much of his early trades union time working with miners round compensation and health services.... The central statism of the post-war reforms nearly obliterated this tradition-but not totally.

On the mainland of Europe the centre-left has developed these traditions in a much fuller way to demonstrate that diverse organisations can better intervene to meet social goals. Hospitals in Germany, for example, may be national state institutions but they may also be local government, private, religious or mutual organizations. This provides a very different framework for development that NHS hospitals that up until now can only be owned by a member of the national government's Cabinet.

Within the present context of the development of new forms of public services, the rejuvenation of this mutual tradition is a vital part of the development of these ideas. ${ }^{9}$

Reid's call for democratic diversity in health and social policy was echoed by the historically rooted calls of other government ministers. In 2003, Hazel Blears, then Minister for Public Health, saw the nineteenth-century traditions of democratic community as a model for new forms of patient and public involvement in the NHS. ${ }^{10}$

Tony Blair, in a major speech in July 2006 on ways of improving public health by promoting healthy living, based his speech on an extensive historical analysis of the role of

\footnotetext{
${ }^{8}$ Alan Milburn speech 14 Nov. 2002 taken from TheyWorkForYou.com, accessed 28 Feb. 2008.

${ }^{9}$ John Reid, Localising the National Health Service: gaining greater equity through localism and
}

diversity, London, New Local Government Network, [2003], pp. 24-5.

${ }^{10}$ Hazel Blears, Communities in control: public services and local socialism, London, Fabian Society, 2003. 


\section{Virginia Berridge}

the state in relation to the improvement of health. ${ }^{11}$ Other speeches he made in that period, on criminal justice, social exclusion, and science, also drew strongly on historical perspectives. The general theme was "our nation's future" and history was used at this point as part of an extensive debate on the subject.

These examples could be multiplied. But what do they really mean?

\section{How History is Being Used}

First we should differentiate the different levels at which history is and could be used in policy circles. The interviews showed different routes: direct policy advice to ministers and policy thinking; the deliberations of expert committees; the media use of history with potential policy impact; or historical analysis feeding through at the local level in Primary Care Trusts and other organizations with responsibility for health. These examples are not all-encompassing but make the point that there is no monolithic policy audience for history, or one way in. Nevertheless, the role of national politicians and of central government is clearly the most important. Let us look first at the role of history there. One informant pointed out that history had no formal role. "I've never seen a situation where a formal historical analysis is sought ... Policy makers find kudos in innovation, but often that is not evidence based. Policy makers feel evidence is for other people. Evidence is for clinicians ...". ${ }^{12}$ Using history was thus tied into a more general problem about the sources of advice and evidence within government. A survey of senior Whitehall policy makers in September 2005 presented by Dr Phil Davies, head of the Social Researchers Office of the Prime Minister's Strategy Unit, itemized sources of information used by senior policy makers in order of importance. Special advisers came top of the list, followed by "experts", think-tanks, lobbyists and pressure groups, professional associations, the media, and finally constituents and users. Academics and their evidence were "not on the radar" (unless, of course, as part of one or other preceding sources of information). ${ }^{13} \mathrm{Dr}$ Davies, when consulted, could not think of an instance where history had been used even in this attenuated process. ${ }^{14}$

But history was, nonetheless, being used in policy making. The interviews uncovered a number of more ad hoc processes of using history in government. Let us look at some examples of this from different settings. For members of expert committees, for example, precedent was important: members used the history of their committee and its past decision making to try to learn from it.

Our advice was founded on an analysis of what had gone wrong in the handling of X [a health issue] - there was a reference to the past and a learning from the past.... The secretariat provided a summary of when an issue was last discussed and what the issues were then. We may otherwise come to a contradictory decision-we were always operating on knowledge of what was going before $\ldots{ }^{15}$

\footnotetext{
${ }^{11}$ http://www.number10.gov.uk/output/ Page9921.asp, accessed 26 Feb. 2008.

${ }^{12}$ Interview with senior public health professional by Virginia Berridge, 17 Jan. 2006.

${ }^{13}$ Presented at a workshop on 'Conducting and commissioning syntheses for managers
}

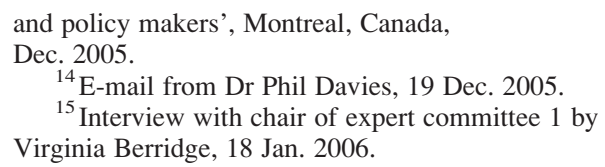




\section{History's Role in Health Policy Making}

The chair of another expert committee recalled a similar process. "We talk about recent history a great deal ... we're always thinking about those things. There are people who've lived through it." 16

This was a process of the committee operating by precedent and using access to its own documentation, minutes and the memories of those who had been involved. A similar process was described in the recent changes around the organization of health protection in the UK and the setting up of the Health Protection Agency.

There we have looked back at the PHLS [Public Health Laboratory Service] and how it was constructed and created. The PHLS shed a lot of labs and there was concern about the configuration of the organization ... The labs went out at the creation of the HPA [Health Protection Agency] ... we talked to people who'd been part of it-it is an ongoing debate... The PHLS played an important role in infectious disease public health-now it's the HPA and the NHS-they are separate and the linkage is a cause of concern. ${ }^{17}$

This was a process akin to legal review with a smattering of oral history: the committee reviewed its own documentation to make sure it was being consistent in its decision making, or was not repeating mistakes. Those with long-term personal involvement were seen as having privileged knowledge to impart.

At the level of high politics, a different process operated. During the early years of the twenty-first century when there was a focus of political attention in government on the NHS and a rethinking of direction. One adviser recalled:

... a good deal of reference to history. It was back to 1948. Alan Milburn's speeches in June 2003-laced through many of those was reference to Bevan's aspirations, how they were still relevant but needed modernization ... Alan was more inclined to invoke history and what Bevan wrote $\ldots{ }^{18}$

Seminars were set up of around fifteen or twenty academics on issues such as patient choice or choice in key services, and the key issues would be distilled back to the Minister. "We didn't specifically invite historians-but the people there had experience of historical context." 19

Different ministers had different ways of operating and also of using history. Whereas Milburn liked to go into detail, and to draw on the seminar process described above, his successor, John Reid, wanted shorter submissions. Both ministers were historians by training. Reid had a PhD in West African history, and thus his own view of history. His health adviser, Paul Corrigan, shared his questioning view of the state (expressed in the pamphlet quoted at the start). Reid was:

... drawing on his own view of history adjusted to the New Labour position ... One day Corrigan sat down with John and drew lines from the sixteenth- and seventeenth-century guilds up to the present. You got the Royal Colleges up to the NHS, then the Poor Law and social insurance and a gap in the middle when people were not really provided for. The NHS was up and running but still the Royal Colleges were regulating the supply of doctors ... ${ }^{20}$

\footnotetext{
${ }^{16}$ Interview with chair of expert committee 2 by Virginia Berridge, 6 March 2006.

${ }^{17}$ Ibid.

${ }^{18}$ Interview with policy adviser 1 by Virginia Berridge, 2 March 2006.
}

\footnotetext{
${ }^{19}$ Ibid. Among the names mentioned in this context were Professors Nick Black and Nick Mays from LSHTM.

${ }^{20}$ Interview with political adviser by Virginia Berridge, 5 April 2006.
} 


\section{Virginia Berridge}

The Shipman case was another example brought into the equation, with discussion of the history of the General Medical Council and its regulatory role. This rather different view of history also had its political uses. My informant commented that current developments could thereby assume a veneer of respectability in political circles by their association with long established traditions. NHS reforms could be seen as part of a lineage from the pastan important process where the heritage of the NHS and Bevan was so strong.

As well as differences between ministers, the issue of institutional memory, which had also affected the operation of expert committees, was important. There was a lack of such memory within government. Advisers commented that there were few people in government with a developed sense of political history and tactics. Civil servants rarely stayed in post for long, and one adviser found himself the only source of institutional memory in being able to think back to the Thatcher market reforms in health and even to supply a copy of a report which others in the department did not know existed.

The rhythm of working in government was also important, with many issues on the agenda at any one time. There were times when history might be inserted and others when it would be impossible. There was some reading time over the weekend, but not during the week. The operation of advisers in government who filtered and selected from other sources was important. Particular points in the policy-making cycle were also more "open" than others. Interviewees commented that speech writing was an important time when all sorts of ideas would be knocked around and the opportunity for a variety of intellectual input, as filtered by advisers, was there. One informant described how the gestation of a major speech would start with a seminar to which leading academics in the field would be invited: the Prime Minister would attend but would listen and not speak. Some participants would be asked to write three or four page comments on their research and views which then went into the PM's reading for the weekend. By the time the speech was written, the background, including the history, would have been absorbed.

\section{The Role of Historians}

It is obvious from the vignettes of the operation of history in government that my informants did not relate their activities to the names of specific historians or historical positions and interpretations. Interviewees were asked whether they had used the work of any health historians or whether any particular names came to mind. Relatively few were mentioned. One adviser commented that he had used "people like Rudolf Klein not Frank Honigsbaum-Rudolf was more contemporary about the implications. I had no contact with Charles Webster, but would draw on his writings. Rudolf has always had that interesthe knows what's going on". 21

One of John Reid's speeches for the Fabians was written with the assistance of "a guy studying for a PhD in Labour History at Oxford ... he was known by an MP in Scotland and used as an historical researcher". ${ }^{22}$ Peter Hennessy's name was mentioned, as was Roy Porter's for health, the latter for "checking the facts". Nicholas Timmins and the Joseph Rowntree archive had been used for a speech on the welfare state. Where one

\footnotetext{
${ }^{21}$ Interview with policy adviser 1 by Virginia $\quad{ }^{22}$ Ibid. Berridge, 2 March 2006.
} 


\section{History's Role in Health Policy Making}

speech was concerned, the writer had used material already in his head from undergraduate work. The only other historian's name which came up in this very imperfect sample was that of Irvine Loudon, who was mentioned in two contexts. A senior public health professional with a strong interest in primary health care knew of his work on the history of general practice. The other example was perhaps rather separate from the day to day business of policy making. A colleague researching maternal health and the safe motherhood movement drew attention to the importance of historical perspectives in forming the policy outlook of that movement. Loudon's work was widely known and used, although the policy "message" drawn from his writing varied across the safe motherhood field. ${ }^{23}$ Safe motherhood advocates drew different messages from Loudon, dependent on their own agendas in the present. The role of history seemed to be waning as the field developed a broader basis of research evidence. This was perhaps an example of the type of totemic role of historians-which also finds echoes in the drugs field, where the work of historians has seeped through over a period of time, but where historical "messages" can be misunderstood or used for particular policy purposes. $^{24}$

Historians were also used who were high profile in fields unrelated to health. In 2006, the NHS Confederation had an historian as keynote speaker for its annual conference. This was the historian, David Starkey, speaking about the role of leadership, presumably with examples from the Tudor period. ${ }^{25}$ One of the organizers of the meeting commented, "To some extent, he was there as entertainment."26

Historians who were cited or used were thus of three sorts: those with close existing connections to policy, who knew the policy scene; those with a media profile, whether appropriate or not; and those, like Loudon, who wrote accessibly and addressed a medical audience in health publications, who appeared to have a message for policy. Unusually for the health field, which tends to be a monograph free zone, over-reliant on databases, Loudon's book was also well known, but his impact was different to the direct impact in the day-to-day world of policy. ${ }^{27}$ Another book which also came on the scene during my research was the history of the Chief Medical Officer (CMO), written as a collaboration between the current CMO and an historian, Sally Sheard. However, one colleague asked me if I had seen "Liam's book". 28

\footnotetext{
${ }^{23}$ K Storeng, D Behague, O Campbell, ‘An anthropological exploration of the uses of historical constructions by key players in the maternal health field', paper presented to LSHTM History Centre workshop on maternal health, May 2006, and interview with Katerini Storeng by Virginia Berridge; Irvine Loudon Death in childbirth, Oxford, Clarendon Press, 1992.

${ }^{24}$ These comments illustrate the role of history as "enlightenment" drawing on theories of the relationship between research and policy. See Virginia Berridge, 'Making health policy', in Virginia Berridge (ed.), Making health policy: networks in research and policy after 1945, Amsterdam and New York, Rodopi, 2005, pp. 5-36.
}

\footnotetext{
25 'Lessons from history 1; leadership, Dr David Starkey, author, historian and broadcaster',

'Achieving value for patients and the public', NHS Confederation conference, 14-16 June, 2006. An attendee at the conference commented on what a good speaker Starkey was, but could not remember what he had said.

${ }^{26}$ Interview with health service representative by Virginia Berridge, 25 July 2006.

${ }^{27}$ Loudon, op. cit., note 23 above.

${ }^{28}$ Comment to Virginia Berridge at an LSHTM function. Dr Sheard was the book's main author, as I pointed out. Sally Sheard and Liam Donaldson, The nation's doctor: the role of the Chief Medical Officer, Oxford, Radcliffe Publishing, 2006.
} 


\section{Virginia Berridge}

\section{Interpretations and Time Frames}

Loudon's work was being used to advance an interpretation of history. But this was not a contested interpretation; no work with a different view was used. One interviewee mentioned competing interpretations as a problem but also a potential strength of history.

There are problems with history - there are a multitude of opinions. There's historians and how they present their conclusions. There's one historian's interpretation and you might get a different historian giving a different interpretation-that would be very worrying. However, two legal opinions are better than one. ${ }^{29}$

This view was sophisticated in that it recognized that history was not simply incontrovertible "fact". Few in the health field seem to have reached this level of understanding of history: this may be why "the facts" are so often invoked without the historians being considered alongside them.

Interpretation was a problem, but so, too, was time frame. The history which was used often focused on particular periods, and ignored others which might also have lessons to impart. The NHS and the invocation of Bevan was one, understandable enough, example. Apart from the use of David Starkey, there was little or no understanding that pre-1948 health service history had any utility for policy analysis. For public health, it was the opposite. Here the nineteenth century and Edwin Chadwick was the "useable history" and there was little discussion in the field or among politicians of what happened after that. This lack of a useable history of public health was particularly noticeable in Blair's July 2006 speech on public health, which faltered when it reached the post-Second World War era. ${ }^{30}$

There are also areas of health policy where relevant historical work exists but is not known to policy makers. One such is the history of vaccination. I questioned interviewees on this and other areas which could be useful. The recent efflorescence of historical work on the inter-war health services might well be considered relevant to discussion of the "patchwork" of service provision today. Neither areas of work were known or seen as relevant, at least to my interviewees. One commented in answer to this question, "My view is that it's potentially valuable, but it would have to be fairly recent. In modern society and with modern structures, it's difficult to extrapolate from the more distant past up to the present day." ${ }^{31}$

At an LSHTM seminar on comparative views of the role of expert committees in current vaccination policy at which the chair of the Joint Committee on Vaccination and Immunization and his US counterpart discussed how their roles and their committees differed, I drew attention, as part of the discussion of current opposition to vaccination, to historical research which had shown the strong tradition of popular opposition to the coercive power of the state and the linking of anti-vaccinationism with working-class radicalism. This research was unknown to both speakers and also to members of the audience who included other policy advisers. ${ }^{32}$

\footnotetext{
${ }^{29}$ Interview with chair of expert committee 1 by Virginia Berridge, 18 Jan. 2006.

${ }^{30}$ The speech commented that "diseases of affluence" were hardly public health issues at all and were not epidemics in the epidemiological sense. This begs the question of the redefinition of public health after the Second World War.
}

\footnotetext{
${ }^{31}$ Interview with expert committee chair 2 by Virginia Berridge, 6 March 2006.

${ }^{32}$ Among several e-mails I received after the seminar one from a colleague asked me how valid the historical work was.
} 


\section{History's Role in Health Policy Making}

Time frame was awkward in other ways. There could be problems with more recent events. Interviewees commented that it was difficult in politics to admit to something having been tried before. The government was paying attention to the 1990 health service reforms, but,

... we are not allowed to use the word "fundholding" ... that's someone else's reforms the government spent three years dismantling ... there's the use of history in an odd way ... it's difficult to admit to anything happening before ... 33

There was thus a tendency in government to justify new initiatives by reference to their lineage elsewhere in Europe rather than by analogy with recent history. ${ }^{34}$ A process of "rebadging" took place in which the history, even if it was known, was not an appropriate form of evidence or justification to use. ${ }^{35}$ This is linked to more general issues of timing and impact when history is used.

\section{Historian Free Data: Statistics and Other Archives}

What the interviews revealed was that history was being used but mostly without historians being involved. History was represented and presented by other interests in the policy field. Two other "uses of history" reinforce this point. Firstly, the use of quantitative data. Statistics are a form of historical evidence with a better "fit" with established ways of thinking in health circles: their use seems to avoid the problem of historical interpretation. Recent research on the future of pandemic flu has drawn on data from the 1918 flu epidemic and has used historical evidence in this way. The work of mathematical modellers on the possible influenza epidemic has used the evidence of the past. Ferguson and his co-authors' paper in Nature on strategies for mitigating an influenza pandemic concludes, "Estimates of policy effectiveness will change if the characteristics of a future pandemic strain differ substantially from those seen in past pandemics." ${ }^{36}$ Other researchers have used historical data in work which looks at the role and spread of malaria. ${ }^{37}$ One policy informant mentioned the publication of data which looked at calorific intake over time and which had indicated that obesity was a matter of lack of exercise. There are ways in which the work of historians can be built into this sort of analysis. At a recent LSHTM seminar with environmental epidemiologists with interests in time series data, further available series and their locations were introduced by historian colleagues. ${ }^{38}$

Secondly, the interviews also revealed a use of documents to search for historical precedent. This is another way of "using history" in policy without using historians.

\footnotetext{
${ }^{33}$ Interview with health service representative by Virginia Berridge, 25 July 2006.

${ }^{34}$ One of my informants saw foundation trusts as "rebadged" in this way by analogy with Spain and Sweden, who had taken ideas from the UK in the first place.

${ }^{35}$ The same process took place with the recent moves to introduce (in fact to re-introduce) "fixing rooms" into British drug services. This was an idea which had been tried in the 1960s.

${ }^{36}$ Neil M Ferguson, Derek A Cummings, Christophe Fraser, James C Cajka, Philip C Colley,
}

\author{
Donald S Burke, 'Strategies for mitigating an \\ influenza pandemic', Nature, 2006, 442: 448-52, \\ e-pub ahead of print 26 April. \\ ${ }^{37}$ Katrin Gaardbo Kuhn, Diarmid H Campbell- \\ Lendrum, Ben Armstrong and Clive R Davies, \\ 'Malaria in Britain: past, present and future', PNAS, \\ 2003, 100: 9997-10001, originally published online \\ 11 Aug. 2003. \\ ${ }^{38}$ Martin Gorsky gave an overview of available \\ data such as Registrar General reports and health \\ statistics to a joint meeting with the environmental \\ research group at LSHTM, 1 March 2007.
}




\section{Virginia Berridge}

"The document" has assumed particular significance in public health research. Such historian free documentary research is likely to expand in future through technology and open access to material. One committee chair mentioned the future availability of expert committee minutes on the web. In other areas, for example tobacco archives, historical material is already available but has mostly been used by researchers with an activist agenda or by public health advocates, not by historians.

This type of historical research has often been used in the law courts. The linking of such research to legal agendas has meant that methodologies which differ from standard historical ways of working have come into play. Non-historian colleagues in the LSHTM and elsewhere research and develop interpretation in a collective fashion which is different to the process of competing or diverse interpretation, based on differing use of a range of archives and sources, as is common in historical method. Their work did not involve access to sources other than industry ones or knowledge of the historiography of the field. ${ }^{39}$ Recently the tobacco advocacy field has begun to discuss how this use of documents can be refined and developed, but the use of historians to advise has been limited. ${ }^{40}$ Yet the policy salience of such work has been considerable: the House of Commons Health committee report on the tobacco industry called in 2000 for access to industry archives to be a priority. ${ }^{41}$

\section{Role of the Media}

The media can be a key conduit impacting on policy. In my previous study, I cited the media's use of Abigail Wood's work on foot and mouth disease which fed into a different policy understanding of the role of vaccination rather than slaughter in dealing with this disease, although in rather a different way to that originally intended. ${ }^{42}$ History and its role in foot and mouth was indeed mentioned by one of my interviewees. But this is perhaps a rare example, using history in a crisis situation when policy makers were searching for answers. ${ }^{43}$ At a seminar for BBC news editors attended by the author, the newsmen and newswomen defended their use of history. The examples they cited did use history as part of their coverage but mostly for foreign policy. Social policy coverage was largely history free and, when questioned, few editors could think of how history might be used in that area. ${ }^{44}$ Newsnight has since introduced a history slot into its news coverage, and this is fronted by the journalist/historian Greg Neale: health topics have made their appearance. ${ }^{45}$ The items appear separately in the programme rather than as part of the overall news

\footnotetext{
${ }^{39}$ Presentation by Kelley Lee and Najda Doyle to History Group at LSHTM, 16 March 2006. A researcher scans material in the Guildford tobacco archive and all the researchers writing a paper use that material. An interpretation would be developed but would not be published until all had viewed the same material and had agreed that the interpretation was the correct one. This way of working came about because of the requirements of legal process.

${ }^{40}$ E D Balbach and E M Barbeau, 'Beyond quagmires: the evolving quality of documents research', Tobacco Control, 2005, 14: $361-2$.
}

\footnotetext{
${ }^{41}$ House of Commons, session 1999-2000, Health Committee, The tobacco industry and the health risks of smoking, second report, 27-I, London, Stationery Office, vol. 1, report and proceedings of the committee.

${ }^{42}$ Discussed in Berridge, op. cit., note 2 above, p. 514.

${ }^{43}$ AIDS provided a similar example.

${ }^{44}$ Lunchtime seminar at BBC White City attended by David Cannadine, Pat Thane and Virginia Berridge, and organized by Mark Damazer.

${ }^{45}$ Including a piece on the smoking ban, in which Virginia Berridge was involved.
} 


\section{History's Role in Health Policy Making}

analysis but this is nevertheless a programme which politicians look at. One informant discounted the role of the media- "we wanted to avoid the strident voices of the lobbywe can hear those people on the TV all the time". ${ }^{46}$ But historians on the media were a different matter. Some have seen the role of media historians as problematic, since they become the first port of call, with the apparent ability to write about every topic, whether they know much about it or not. ${ }^{47}$ Nevertheless, research has demonstrated the key importance of the media in defining agendas to politicians. ${ }^{48}$

For health, medical journals are a key conduit for new stories in the general media, as any week's coverage will reveal, part of that "circuit of mass communication" whereby ideas filter through and gain policy currency. But access to these outlets for health history and for the interpretative work of historians can be difficult. There are practical issues such as the need for most historians to publish elsewhere for career purposes and for the Research Assessment Exercise (RAE), the short length allowed, and so on. There are also more intangible issues of language, contacts and networks in health. During the course of this study, two of my colleagues, one a doctor and one a historian, submitted history papers to a leading medical journal. The doctor's piece was accepted and the historian's was not. The "message" in the first paper was more attuned to contemporary preconceptions in health, even though historically it was debatable. Historians can be at a disadvantage where they are not part of the networks which operate in health. ${ }^{49}$ History is used in the medical journals but often it is relegated to the Christmas issue, part of the more relaxed entertainment of the holiday season. ${ }^{50}$ However, the recent historical competition by the British Medical Journal to pinpoint the greatest contributions to human health shows one way in which history can be used imaginatively. ${ }^{51}$

\section{Funders and Foresight}

Funding bodies have a commitment to bringing evidence, including historical evidence, to bear on "users" in policy and elsewhere. The main social science and humanities funding bodies, the Economic and Social Research Council (ESRC) and the Arts and Humanities Research Council (AHRC), both support the funding of historical research for this purpose. They are also beginning to trace how such work is used in policy and practice, and have set up "knowledge transfer" mechanisms which have the potential to involve the work of historians. ${ }^{52}$ The Wellcome Trust is also tracing the impact of research it has

\footnotetext{
${ }^{46}$ Interview with speech writer by Virginia Berridge, 7 Nov. 2006.

${ }^{47}$ Quentin Skinner speaking at a British Academy meeting on history and public life referred to the role of "public intellectuals" on the French model-these were worth hearing on any topic even if not expert. British Academy seminar, 19 Oct. 2005.

${ }^{48}$ Virginia Berridge, AIDS in the UK: the making of policy, 1981-1994, Oxford University Press, 1996.

${ }^{49}$ A number of journals are now starting to run historical series on the model of the long running one in the American Journal of Public Health. Some are edited by historians and
}

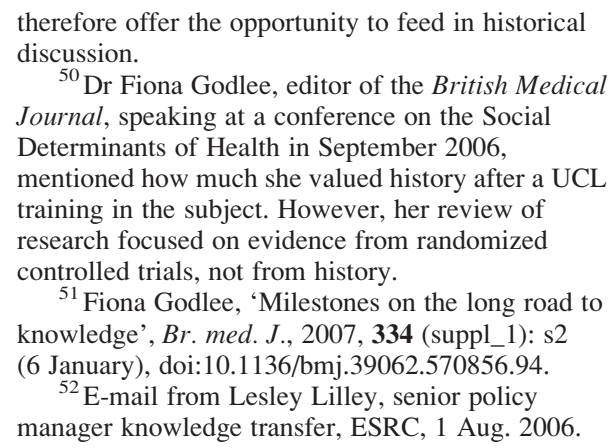




\section{Virginia Berridge}

funded. ${ }^{53}$ The ESRC now has a placement scheme whereby researchers can spend some time in a government department.

Recently, a wider range of funders have begun to use history and to fund it. The Joseph Rowntree Foundation has funded work on temperance and alcohol policy, and other initiatives by a range of bodies not known for their previous funding of history have come about in recent months. ${ }^{54}$

A different style of policy-related funding of history has come through the Foresight initiatives, based in the Office of Science and Technology. These take a twenty year forward look at policy issues. Two at least have involved reference to history-one on the future of psychoactive substances and one on the future of infectious diseases. ${ }^{55}$ Here the researchers are set to answer questions defined by the civil servants and policy makers and to provide reviews of historical material and interpretation, rather than primary research. The author's experience of the psychoactive substances initiative was instructive in the "uses of health history". The historians' interpretation was appealing to the civil servants and used in innovative ways. The Henley Centre was commissioned to develop scenarios for the future, based on the initial position papers, which included history. In addition to that historical position paper, I was asked to write the explanation of the sequence of events which could have led to the scenarios which the Henley team had developed. ${ }^{56}$ History was being used to outline the future, but it was a future which the historians had had no role in predicting. It was a creative use of the subject, although the historical work could also have been used more directly to develop the future scenarios themselves.

\section{Nye Bevan, John Snow, Edwin Chadwick-and Social Science}

From the point of view of historians there is a problem about the use of history in health policy making. Areas like NHS policy making or public health are far from history free. In fact they are often full of historical reference. The UK Public Health Association chief executive, Angela Mawle, used John Snow extensively as an historical exemplar in her introduction to the 2006 meeting of the annual public health forum. ${ }^{57}$ Likewise, when the author attended the opening meeting of the new health services research network in June 2006, the final discussion between Rudolf Klein, the journalist/historian Nicholas Timmins, and Angela Coulter of the Picker Institute, chaired by Julian Le Grand, was dominated by historical perspectives. Le Grand, Timmins and Klein in particular

\footnotetext{
53 'Getting research into policy and practice', Wellcome News, Nov. 2007, issue 52, pp. 12-13.

${ }^{54}$ Among those in which the Centre for History in Public Health has been involved are: a project on binge drinking funded by the Alcohol Education and Research Council; a study of the childhood leukemia trials funded by the Medical Research Council (MRC), and a study of health education literature and what it reveals for the post-war history of public health and future policy directions, funded by the National Institute for Clinical Excellence (NICE). The MRC and NICE approached our Centre to carry out this
}

work, a change from normal grant funding mechanisms.

${ }^{55}$ Virginia Berridge and Tim Hickman, 'History and the future of psychoactive substances', position paper for Foresight initiative, www.foresight.gov.uk, 2005; Michael Worboys and Abigail Woods, 'Detection of infectious diseases: history review', Foresight, 2006.

${ }^{56}$ The Henley Centre is a management think-tank.

${ }^{57}$ See Public Health News, 27 March 2006, p. 10. 


\section{History's Role in Health Policy Making}

discussed the issue of choice by reference to the choice which had existed in the NHS after $1948 .^{58}$

When policy advisers were also academics, history came into their teaching. One policy adviser mentioned his use of Simon Szreter's critique of Thomas McKeown as informing the discussion with overseas students. But this type of historical debate did not filter through into policy advice, perhaps because it was more diffuse. ${ }^{59}$

My interviews reveal just this; that history is being used in an ad hoc way, mostly without the involvement of historians. Historians are mainly seen as providers of the raw materials for analysis. Policy makers like to use history but they do not usually see historians or historical interpretation as a necessary part of the frame. There is little knowledge of the interpretative role of history, and views of history are dominated, in the view of historians, by out-of-date perceptions or by mistaken views of personalities and "great men". Invoking Nye Bevan is a cottage industry among health ministers. But there are good reasons for this. It is not just because of lack of knowledge of anything else but also because of the necessary dynamic of policy making. One informant analysed this process vividly:

I was at a meeting with Paul Corrigan where he was the only person able to articulate what the $£ 50$ billion more spent on the NHS by 2008 would have achieved. Corrigan said, "At last the promise of 1948 will have been delivered" ... it's like ringing the bell in Mass ... It helped with the narrative, to fit the reforms together, to develop what the narrative was. ${ }^{60}$

Bevan was inherent in the message of policy; another form of history would not have fitted so easily. The same was true of the narrative of the late Blair government. Blair had the image in the late 1990s of running a "history free" government, but by 2006 the political rationale dictated a changed role for the past.

History started to come in because we were at a particular point in the political cycle ... We wanted to be able to survey what government had done and beyond that, how things have changed over a longer cycle.... The questions confronting government at the end of the twentieth century are different to societies before-success brings its own problems ... there are trends of which government is part, but not the central player ... ${ }^{61}$

When narratives are changing in this way at the political level, it is difficult for historians to be aware of the direction of the current narrative within government. Historians mostly lack those networks and entrée. Journalist historians and social scientists with policy networks are clearly at an advantage, with more policy antennae. Social scientists in advisory positions are key users and promoters of history for policy advice. However, the history they are using is not always in accord with what historians are saying and this is a general problem in the health advisory field. ${ }^{62}$

\footnotetext{
${ }^{58}$ Author's notes of the debate.

${ }^{59}$ It was absent from Tony Blair's public health speech which attributed public health improvement in the nineteenth century in part to the benefits of medical research.

${ }^{60}$ Interview with health service representative by Virginia Berridge, 25 July 2006.
}

\footnotetext{
${ }^{61}$ Interview with speech writer by Virginia Berridge, 7 Nov. 2006.

${ }^{62}$ See, for example, John Welshman, 'Knights, knaves, pawns and queens: attitudes to behaviour in postwar Britain', J. Epidemiol. Community Health, 2007, 61: 95-7, which takes issue with Julian Le Grand's influential thesis on post-war Britain.
} 


\section{Virginia Berridge}

\section{Ways Forward}

There are some positive ways forward which could be considered. I will categorize these in three ways: developing the narrative; using informal networks; the rational modeldeveloping formal mechanisms.

Developing the narrative could be a mutual process in which policy makers realize that they need history and historians realize that what they are researching and writing about has a potential message for policy. One informant in the policy field spoke of the need for historical work. "Historians are better than other disciplines - they tend to write clearly and don't purport to tell us what to do. They are different and useful. This is not true of political scientists who tend to tell us what to do. Historians are not threatening but can be enlightening."63

This is the classic "enlightenment" view of research which has been much discussed by the analysts of the research/policy relationship. However, this informant recognized that historians in particular areas such as health were difficult to find. His view was that the impetus had to come from policy on terms which historians could accept. But historians do not need to remain passive in the interim. They could develop that narrative, deepen or challenge it though more appropriate research findings.

How to do this? My interviews illustrated the important role which networks play. These are often quite personal, the more so the nearer one gets to the high political levels of government. The name of Paul Corrigan as adviser and historical discussant came up in several health discussions. The argument for historical work needs to be made by the use of those networks by historians and also by speaking to our allies in social science and in the funding bodies. Social scientists in policy positions emerged as key "users" of history in this study, as "history brokers", as did politicians with historical backgrounds, of which there are quite a few in government. These could be engaged more effectively. The "knowledge transfer" mechanisms operate both formally and informally and these could be built on. Here I mean both formal mechanisms like seminars bringing the two sides together, and also the many informal means of transfer and the use of any opportunities which may emerge. Often this is simply luck or initiative.

What about the rational model? As I have written elsewhere, the rational model of evidence and policy is far from reality. ${ }^{64}$ The evidence-based medicine movement has tended to concentrate on improving the processes by which research translates into policy without recognizing the fundamental political and conceptual constraints which also operate. These have been more the province of the social studies of science field. But if we look at the processes of "knowledge transfer" of history there are matters which could be improved.

This is an issue of making sense of complexity, of communication and language across the history/policy boundary. The new open access policies being introduced for health history funded by the Wellcome Trust and by the research councils may help here. Although historians have been wary about the impact of these changes, at least historical work will be included in the databases used by most researchers in the health field. History should begin to find its place in the health industry of systematic review,

\footnotetext{
${ }^{63}$ Interview with speech writer by Virginia Berridge, 7 Nov. 2006.
}

\footnotetext{
${ }^{64}$ Interview with policy adviser 1 by Virginia Berridge, 2 March 2006.
} 


\section{History's Role in Health Policy Making}

which is part of the rational model of research and policy making and the evidence-based movement. Access to historical work has been quite limited until now.

The use of history needs to be rethought from both sides of the boundary. Historians need to think a little more widely and to articulate their ideas more clearly. As one policy adviser said, "Are there human truths and social science generalisms which carry over geography and time?" Can the history of earlier times speak to the present? Historians need to become better at drawing out general principles from their work and at communicating in policy terms. The citation of Rudolf Klein as a usable historian was instructive. The attitude of historians is changing here. The recent 'History of the Social Determinants of Health' conference showed historians prepared to operate in a policy environment in a way which most would not have contemplated a decade ago. ${ }^{65}$ But practitioners in the health field often find "the message" of historians difficult to discern. Colleagues at the LSHTM have questioned me after historical seminars, saying that the detail is fascinating, but what was the speaker trying to say? When I summed up the work of a well-known historian in a lecture, two members of the audience told me that at last they knew what his argument was. They had not been clear before. History also needs its knowledge brokers or systems of systematic review.

The boundary of language and modes of expression is a two way matter. Both sides need to think about this. Civil servants were notably absent from the discussion in my interviews as channels of influence for history. It may be because they move often, it may be because of these problems of language and approach. During the Foresight exercise, a Department of Health civil servant told me that she found our position paper, which we thought we had made accessible, very hard to comprehend. ${ }^{66}$ One historian in a conversation suggested that there should be CPD (continuous professional development) for civil servants so that they could understand what historians were saying. Some health historians have been running historical training days for Primary Care Trusts. ${ }^{67}$ Perhaps this idea could be extended to the policy field. The National School of Government runs courses in evidencebased policy making but there is no evidence that use of historical perspectives form part of the training. ${ }^{68}$ The original function of the "official histories" of particular areas of government was to stimulate collective memory. In the 1950s Norman Brook as Cabinet Secretary and head of the Civil Service wrote to all departments requiring them to create files which summarized past developments. ${ }^{69}$ Such reviews could also feed, in the present policy set up, into the work of enquiries and parliamentary committees.

One initiative has begun to operate this "rational" model for history and to improve processes of interaction and of clarity of communication. The history and policy network and website offers a potential "knowledge broking" mechanism. ${ }^{70}$ The Wellcome Trust

\footnotetext{
${ }^{65}$ Interview with policy adviser 2 by Virginia Berridge, 16 May 2006. Virginia Berridge, 'The Black report: reinterpreting history', in Harold J Cook, Sanjoy Battacharya, and Anne Hardy (eds), History of the social determinants of health: global histories, contemporary debates, Hyderabad, Orient Longman, 2008, pp. 111-18.

${ }^{66}$ Her comments on it showed she did not understand the concept of change over time: everything was interpreted as if it referred to the present.
}

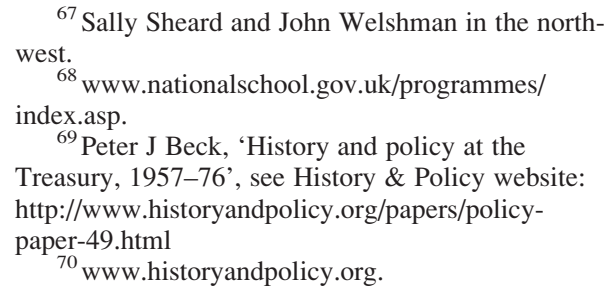




\section{Virginia Berridge}

public understanding programme which has so far concentrated on the "public" rather than the policy uses of history could also pay attention to this crucial interface. The Trust makes little use of the historical research it funds in terms of policy relevance. Such a funding body is potentially a key vector for the historical message about health and science, given its funding mix of historians, health personnel and scientists.

Timing is also a key consideration, in a number of different ways. There seem to be cycles in the use of history in particular areas and the sort of history used. The use of history in the "late Blair" period of government underlines the fact that 2007 was probably a good time for inserting the message of history into policy. There is the timing of publication and intervention, too. One historian lamented to me that his book on alcohol had not been published when alcohol policy was centre stage. The timing of insertion into policy needs to be carefully managed.

As with much of policy making itself, the impression is that the current use of history in policy is itself historically contingent, dependent on personal networks, self-help, and particular policy situations-sometimes a crisis where there is nothing apart from history to hold on to. Or history fulfils a rhetorical role which has its own ancestry in the nineteenth-century politicians' use of the past or the radicals' invocation of "Old Corruption" and the "Norman Yoke". 71

But policy makers are using history, albeit not in ways which all of us might like, and there is goodwill towards the subject. "Historians have got to be invited in", said one informant. Is a further stage possible? Many historians feel deeply ambivalent about involvement, given the predilection of policy makers to find evidence to suit intended policies rather than the other way round. But the Downing Street speech writer was right: historians do offer a form of analysis which in its ability to segment and analyse the issues comprehensively and dispassionately over time, is matched by no other discipline. Health policy specialists have pointed to a failure to learn from experience as one of the main reasons for organizational failure in health. One could cite the current government's focus on NHS reorganization as an example where the history of reorganization could have counselled caution. The role of health in local government is another under-exploited historical area. The Cooksey review of health research funding has an historical introduction, but it is unclear if this preface informed the main report's recommendations. In particular the long-standing issue of the boundaries between government health research and the role of the Medical Research Council could have been better understood through historical analysis. ${ }^{72}$ If evidence-based policy and evidence-based medicine are on the agenda, then history should be part of that process. Its ability to open up options is underdeveloped at the policy level. Historians as policy prescribers would only join the ranks of the "usual suspects" in policy making. But as analysts offering the classic function of "enlightenment" they have a perspective which no other discipline can offer. History as analysis offers great insight, interpretative richness and a sophisticated understanding of the past. For the lack of these, current policy is the poorer.

\footnotetext{
${ }^{71} \mathrm{~V}$ Berridge, 'Popular journalism and working class attitudes, 1854-1886: a study of Reynolds's Newspaper, Lloyd's Weekly Newspaper and the Weekly Times', University of London, PhD thesis, 1976.
}

\footnotetext{
72 'Historical overview of government health policy', Cooksey review background paper: a brief history of government health research policy, http:// www.hm-treasury.gov.uk/independent_reviews/ cooksey_review/cookseyreview_index.cfm.
} 